\title{
Commercial tourism in Tasmania's wilderness threatens the attraction it exploits
}

To the Editor - The Tasmanian Wilderness World Heritage Area (TWWHA) is a vast area -1.5 million hectares - with diverse geology, landforms and vegetation. It is listed under the World Heritage Convention owing to the outstanding value of its natural and cultural features, and has been described by the World Heritage Committee as one of the "last remaining temperate wilderness areas in the world"1 (Fig. 1). However, that status has served to attract increasing numbers of high-end 'eco-tourists', placing the area under development pressure.

The Tasmanian eco-tourism boom has led to Australian governments taking an increasingly economic approach to managing its wilderness ${ }^{2}$. In 2016, the TWWHA management plan was amended to allow for more permanent and pervasive tourism activities than had been permitted under the previous management plan from 1999, which had a predominant conservation focus. The World Heritage Committee has warned that Australia's current management approach risks diminishing the wilderness character of the property as one of its key values and recommended Australia to impose "strict criteria for new tourism development... with the primary goal of protecting the property's... wilderness character" ${ }^{\text {. }}$.

Tools do exist to assess and maintain wilderness character ${ }^{4}$, but they are not mandated by domestic or international law. Furthermore, international law is unclear about what constitutes 'wilderness' and the obligations states have to protect it. Thus, although Australia has 'accepted' the committee's recommendation, it has not implemented it in a meaningful way. This became evident with the first TWWHA development proposal to be considered by the Australian government under the 2016 management plan: the construction of a luxury standing camp with permanent infrastructure at Halls Island in the Central Plateau wilderness area. The site will be

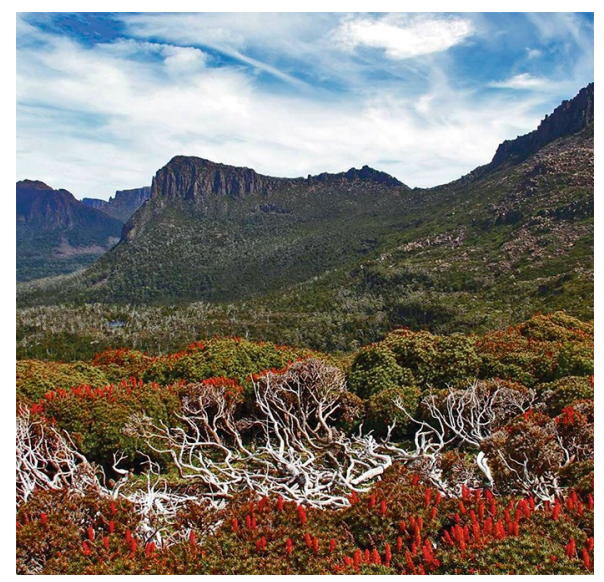

Fig. 1 | Endemic Richea scoparia in bloom, Tasmanian Wilderness World Heritage Area.

accessed by more than 100 helicopter flights per year over areas that previously received few or no overflights - helicopter tourism did not occur under the 1999 management plan.

In July 2018, the statutory council charged with providing expert advice on TWWHA management advised the Australian environment minister that the proposal risks significant impacts on the wilderness character of the site, and should not proceed in the absence of an "agreed framework for assessment" ${ }^{\text {" }}$. Despite this, the minister determined in August 2018 that the proposal could proceed without any detailed assessment of impacts on wilderness values. This is a worrying development. Furthermore, the Halls Island development is only the first of many substantial tourism developments proposed within the TWWHA.

Wilderness need not be free of humans: a variety of uses may be justified depending on the site and the circumstances ${ }^{7}$. However, the essential characteristic of wilderness is that it is primitive and remote from mechanised access ${ }^{8}$. Proper governance requires placing ecological, biological and cultural values above economic returns. The TWWHA decision inverts that hierarchy. We argue that the economic rationalization of wilderness in developed countries such as Australia is dangerous, especially given the wider existential threats to wilderness across the planet ${ }^{9}$. Meaningfully reversing such a trend will require the articulation and adoption of clearer, more rigorous and binding wilderness assessment frameworks within world heritage law and governance. That is an interdisciplinary task for scientists, lawyers and policymakers.

Brendan Gogarty ${ }^{1 *}$, James Kirkpatrick ${ }^{2}$, Nicholas Fitzgerald², Simon Jarman ${ }^{3}$, Phillipa McCormack ${ }^{1}$ and James Marthick ${ }^{4}$ ${ }^{1}$ Faculty of Law, University of Tasmania, Hobart, Tasmania, Australia. ${ }^{2}$ School of Technology, Environments and Design, University of Tasmania, Hobart, Tasmania, Australia. ${ }^{3}$ Curtin University, Bentley, Western Australia, Australia. ${ }^{4}$ Menzies Institute for Medical Research, University of Tasmania, Hobart, Tasmania, Australia. *e-mail:Brendan.gogarty@utas.edu.au

Published online: 19 November 2018 https://doi.org/10.1038/s41559-018-0723-z

References

1. Tasmanian Wilderness Decision 06COM VIII.20, 181 (World Heritage Committee, 1982).

2. Tasmanian Wilderness World Heritage Area Management Plan 2016 (State of Tasmania, 2016).

3. Decision 39 COM 7B.35 (World Heritage Committee, 2015).

4. Mendel, L. C. \& Kirkpatrick, J. B. Landscape Urban Plan. 43, 181-190 (1999).

5. EPBC Notice 2018/8177 (Australian Government Department of Environment \& Energy, 2018).

6. Gogarty, B., Fitzgerald, N. \& McCormack, P. C. Green light for Tasmanian wilderness tourism development defied expert advice. The Conversation (16 October 2018); https://theconversation. com/green-light-for-tasmanian-wilderness-tourismdevelopment-defied-expert-advice-104854

7. Badman, T. et al. World Heritage, Wilderness, and Large Landscapes and Seascapes (IUCN, Gland, 2017).

8. Allen, J. R., Venter, O. \& Watson, J. E. M. Sci. Data 4, 170187 (2017).

9. Watson, J. E. M. et al. Curr. Biol. 26, 2929-2934 (2016).

Competing interests

The authors declare no competing interests. 